\title{
Peran Apoteker dalam Pengobatan Wasir
}

\author{
Indraswari Pitaloka \\ Program Sarjana Farmasi, Fakultas Farmasi, Universitas Padjadjaran, Sumedang 45363 \\ email: indraswaripitaloka@gmail.com
}

\begin{abstract}
Abstrak :
Wasir atau ambeien merupakan istilah populer dari penyakit hemorrhoid, atau dalam bahasa kedokteran disebut piles. Wasir didefinisikan sebagai gejala pembengkakan dan perpindahan bantalan hemorrhoid normal. Gejala hemoroid yang paling umum adalah perdarahan rektum yang terkait dengan gerakan usus, dan benjolan pada luar anus. Pembengkakan bantalan hemorrhoid dan hiperplasia pembuluh darah memainkan peran penting dalam perkembangan wasir, dan bisa menjadi target potensial untuk perawatan medis. Wasir dapat diobati dan dicegah dengan terapi nonfarmakologi seperti memakan makanan tinggi serat, banyak minum air putih, tidak menunda-nunda $B A B$, dan juga dapat diobati dengan salep pereda nyeri yang dijual secara bebas di apotek, maupun dengan resep dokter. Sebagai penderita wasir, terkadang sulit mengetahui sejauh mana wasir dapat diobati dengan pengobatan sederhana di rumah, ataukah sudah harus mendapatkan perawatan dari dokter maupun tindakan operatif lebih lanjut. Oleh karena itu artikel ini menguraikan penyebab wasir yang harus dihindari, tingkat keparahan wasir untuk menilai seberapa parah wasir yang diderita, dan tindakan yang sesuai, sampai pola makan yang disarankan untuk penderita wasir.
\end{abstract}

Keyword : Wasir, Pola Makan, Terapi-Non Farmakologi, Terapi Farmakologi

\section{Outline}

- Pendahuluan

- Cara mengobati wasir

- Peran apoteker dalam pengobatan wasir

- Kesimpulan

\section{Pendahuluan}

Wasir, atau ambeien, dalam istilah kedokteran disbut piles, merupakan penyakit pada bantalan haemorrhoid yang membengkak, dan bergerak tempat dari lokasi normalnya berada, dapat ditemukan diluar anus atau yang disebut dengan hemorrhoid eksternal dan di dalam anus yang tidak dapat dilihat, disebut dengan hemorrhoid internal.

Hemorrhoid merupakan suatu bantalan anal berisi otot halus dan banyak pembuluh darah yang secara normal terdapat dalam rektum, berperan dalam pengaturan tekanan untuk mengeluarkan kotoran dari anus, dan melindungi otot sfingter anus dari kontak langsung dengan kotoran. 
Terdapat tiga bantal anal utama, yang terletak di anterior kanan, posterior kanan dan di sebelah kiri secara lateral dari lubang anus, serta beberapa jumlah bantal kecil yang terletak di antara mereka. Bantal anal pasien yang mengalami wasir menunjukkan perubahan patologis yang signifikan. Perubahan ini termasuk dilatasi vena yang abnormal, trombosis vaskular, proses degeneratif pada serabut kolagen dan jaringan fibroelastik, distorsi dan pecahnya otot subepitel dubur. Selain temuan di atas, juga terjadi reaksi peradangan parah yang melibatkan dinding pembuluh darah dan jaringan ikat di sekitarnya. Kondisi bantalan haemorrhoid yang membengkak inilah yang kemudian disebut dengan ambeien/wasir.

Kondisi tekanan sehingga menimbulkan bantalan haemorrhoid meradang diantaranya yaitu konstipasi (sulit buang air besar) yang disebabkan oleh kurangnya konsumsi serat, kurang minum air mineral, terlalu kuat mengejan, dan terlalu lama berjongkok di toilet.

Kenali Tingkat Keparahan Wasir

- Stage 1 = BAB berdarah/ disertai tetesan darah merah segar saat BAB. Biasanya pembengkakan/ benjolan terjadi di dalam (internal hemorrhoid)

- Stage 2 = Terdapat benjolan yang keluar tiap BAB namun bisa masuk sendiri setiap berhenti meneran tanpa perlu tindakan khusus.

- Stage 3 = Benjolan akan keluar saat mengejan dan harus dilakukan pemasukkan benjolan dengan bantuan dorongan dari luar karena benjolan tidak bisa masuk secara otomatis .

- Stage 4 =Terdapat benjolan keluar, nyeri luar biasa, terjadi pendarahan serta tidak bisa didorong kembali. Membutuhkan tindakan operatif.

Stage 1-2 dapat dilakukan pengobatan dirumah, pengobatan dengan obat resep dokter, maupun tindakan seperti koagulasi dengan infra-merah ataupun tindakan ligasi. Namun untuk stage 3-4 direkomendasikan untuk dilakukan tindakan operasi (Lohsiriwat, 2012).

\section{Cara mengobati Wasir}

Pengobatan wasir dapat dilakukan dengan pereda nyeri, dan perawatan sederhana di rumah saat wasir baru terjadi. Jika wasir 1 minggu tidak mereda setelah pengobatan sederhana di rumah, dan jika terjadi pendarahan hebat, Anda harus segera memeriksakan diri ke dokter.

1. Beberapa Pengobatan dirumah yang dapat Anda lakukan yaitu:

- Duduk dengan bantalan lembut/lunak

Penggunaan bantalan duduk yang lembut akan mencegah bertambah parahnya pembengkakan yang ada, dan mencegah timbulnya pembengkakan yang baru. 
- Meredakan Nyeri dengan perendaman bagian nyeri dengan air hangat

Bath sitz adalah suatu tempat yang dapat menampung air hangat untuk dubur dan pinggul (nama berasal dari bahasa Jerman "sitzen," yang berarti "duduk"). Perendaman ini dapat meredakan gatal, iritasi, dan kejang otot sfingter. Bath sitz ini seperti bak plastik kecil yang muat di atas dudukan toilet, atau Anda bisa duduk di bak mandi (bath tub) dengan air hangat dengan ketinggian beberapa inci. Kebanyakan ahli merekomendasikan berendam dalam bath sitz 20 menit setelah setiap timbul ketidaknyamanan pada usus dan anus dan dua atau tiga kali sehari sebagai tambahan. Hati-hati saat menepuk area dubur sesudahnya; jangan menggosok atau menyeka keras. Anda juga dapat menggunakan pengering rambut untuk mengeringkan area tersebut.

\section{Obat Hemorrhoid}

a. Obat bebas (over the counter) yang dapat Anda beli tanpa resep dokter

Jika Anda pergi ke apotek untuk membeli obat wasir, maka obat yang akan banyak Anda temui adalah obat dengan kandungan herbal karena akhir-akhir ini pengobatan wasir telah bergeser ke pengobatan yang aman.

Obat minum dengan kandungan utama Graptophyllum pictum atau daun ungu merupakan jenis yang umum ditemui di apotek, Graptophyllum pictum atau daun ungu merupakan jenis yang umum ditemui di apotek, terkenal sebagai khasiatnya dalam menyembuhkan luka dan meredakan pembengkakan (Anti-inflamasi). Daun ungu ini biasanya diformulasikan dengan kandungan tambahan Sophora japonica yang memiliki khasiat mengurangi gejala-gejala wasir.

Salep dengan kandungan kombinasi witchazel, horse-chestnut, dan Centella asiatica. Kandungan-kandungan obat wasir di bawah ini merupakaan kandungan salep yang bisa Anda dapatkan tanpa resep dokter, dan tergolong aman untuk mengobati wasir Anda. Jangan khawatir mendengar nama kandungannya yang asing dan terkesan langka, karena obat-obat dapat ditemukan dengan mudah di apotek-apotek di Indonesia.

- Witchazel (Hamamelis virginiana)

Tanaman yang berasal dari Amerika Utara ini memiliki sejarah panjang untuk pengobatan wasir. Ekstrak witchhazel mengandung minyak atsiri, flavonoid dan tanin berkhasiat sebagai astringent (mengerutkan pembengkakan jaringan), anti-inflamasi dan efek anti pendarahan.

- Horse-Chestnut

Meredakan radang dan bengkak, memperbaiki pembuluh darah, dan antioksidan.

- Pegagan ( Centella asiatica)

Kandungan dari pegagan ini memiliki potensi untuk meningkatkan kekuatan jaringan ikat, membantu penyembuhan luka di sekita area hemorrhoid yang membengkak, dan memperbaiki pembuluh darah. 
b. Obat Resep Dokter

- Obat minum

Obat minum yang mengandung senyawa flavonoid berukuran mikro yang terdiri dari $90 \%$ diosmin dan $10 \%$ Hesperidin merupakan obat yang paling umum digunakan pada klinik. Sebuah meta-analisis terbaru untuk pengobatana hemoroid dengan flavonoid tersebut membuktikan bahwa obat menurunkan resiko pendarahan sebesar $67 \%$, menurunkan nyeri persisten sebesar $65 \%$ dan mengurangi tingkat kekambuhan sebesar 47\% (Coello et al., 2006).

- Obat oles luar dan suppositoria

Untuk mengurangi nyeri dan mengurangi peradangan di area sekitar anus, biasanya diresepkan salep atau suppositoria dengan kandungan:

Glyceryl trinitrate: relaksasi dan mengurangi tekanan pada otot anus

Phenylephrin: Memperkecil pembuluh darah di sekitar anus, sehingga mengurangi bengkak dan rasa tidak nyaman

Lignocaine/ Lidokain: Anastetik lokal yang mampu meredakan nyeri

Zinc Oxide: bertindak sebagai adsorben yang mengurangi kelembaban dan gesekan kulit dan menghambat pertumbuhan bakteri tertentu. la juga memiliki sifat astringen yang membantu mengurangi pembengkakan haemorrhoidal, juga membantu melindungi area dari iritasi, dan mengurangi gatal.

Bismut subnitrat: Memiliki efek melindungi area anus, dan mempercepat penyembuhan.

\section{Peran apoteker dalam pengobatan wasir}

Tanyakan pada Apoteker Anda mengenai pemilihan obat yang tepat untuk pengobatan sendiri (swamedikasi) wasir ringan Anda, dan pastikan Anda mendapatkan penjelasan dari Apoteker mengenai khasiat obat wasir yang Anda dapat dari resep dokter. Untuk obat salep dan suppositoria tanyakan pada apoteker Anda bagaimana cara penggunaan yang tepat!

Apoteker adalah tenaga ahli kesehatan yang mengerti betul terapi apa yang cocok untuk swamedikasi.

Cara mencegah kekambuhan wasir

- Makan makanan kaya akan serat

Salah satu terjadinya wasir karena Anda mengejan terlalu kuat. Asal muasal Anda mengejan terlalu kuat yaitu karena Anda kurang makan serat sehingga BAB Anda tidak lancar dan membuat Anda kesulitan setiap akan buang air besar. 
Adapun Makanan Kaya Serat yaitu:

Sayur dan Kacang-kacangan

Sayur merupakan sumber serat yang baik, makanlah lebih banyak:

- Selada, Wortel, Bayam

- Sayur yang diolah kedalam masakan seperti: asparagus, jamur, lobak dan labu

- Brokoli, almon, dan kacang-kacangan lainnya

Buah

Beberapa buah dengan kandungan serat tinggi yaitu:

- Apel dan Pisan

- Peach dan Pir

- Jeruk dan golongan buah Berry

Gandum

Gandum juga merupakan sumber serat tinggi, diantaranya yaitu:

- Oatmeal

- Roti gandum utuh

- Popcorn

- Pasta dengan komposisi tepung

- Menghindari makanan-maknan penyebab konstipasi seperti keju, es krim, makanan cepat saji, snack dan keripik kentang, dan daging.

- Tidak menunda buang air besar dan Tidak berjongkok terlalu lama

Setiap Anda menunda buang air besar, maka kotoran Anda tertahan lebih lama dalam usus, dan usus secara otomatis menyerap kandungan air dari kotoran Anda. Alhasil, kotoran Anda menjadi lebih padat dan lebih sulit dikeluarkan.

Hal ini akan menyebabkan Anda mengejan lebih kuat dan menyebabkan wasir Anda kambuh.

- Banyak minum Air putih

Minum air putih dan cairan lain, seperti jus buah dan sup bening, dapat membantu serat dalam makanan Anda bekerja lebih baik. Tanyakan kepada dokter Anda tentang berapa banyak Anda harus minum setiap hari berdasarkan tingkat kesehatan dan aktivitas Anda dan di mana Anda tinggal.

- Jalan Cepat

Aktivitas aerobik intensitas sedang seperti jalan cepat selama 20-30 menit sehari dapat membantu stimulasi fungsi usus besar. 


\section{Kesimpulan}

Dalam artikel ini dijelaskan penyebab wasir yang harus dihindari, tingkat keparahan wasir untuk menilai seberapa parah wasir yang diderita, dan tindakan yang sesuai, sampai pola makan yang disarankan untuk penderita wasir. Wasir dapat diobati dan dicegah dengan terapi non-farmakologi seperti memakan makanan tinggi serat, banyak minum air putih, tidak menunda-nunda $B A B$, dan juga dapat diobati dengan salep pereda nyeri yang dijual secara bebas di apotek, maupun dengan resep dokter

\section{Daftar Pustaka}

Coello P, Alonso, Mills E, Heels-Ansdell D, López-Yarto M, Zhou Q, Johanson JF, Guyatt G. Fiber for the treatment of hemorrhoids complications: a systematic review and meta-analysis. Am J Gastroenterol. 2006;101:181-188. [PubMed]

Dahl WJ, Stewart ML. Position of the Academy of Nutrition and Dietetics: health implications of dietary fiber. J Acad Nutr Diet. 2015;115(11):1861-1870. PMID 26514720 www.ncbi.nlm.nih.gov/pubmed/26514720.

Grodner M, Escott-Stump S, Dorner S. Carbohydrates. In: Grodner M, Escott-Stump S, Dorner S, eds. Nutritional Foundations and Clinical Applications. 6th ed. Philadelphia, PA: Elsevier Mosby; 2016:chap 5.

Harvard Health Publishing. 2013. Hemorrhoids and what to do about them. Tersedia online di https://www.health.harvard.edu/diseases-andconditions/hemorrhoids_and_what_to_do_about_them [diakses pada 15 november 2018].

Lohsiriwat, Varut. 2012. Hemorrhoids: from basic pathophysiology to clinical management. World journal of gastroenterology, 18(17), 2009-2017.

National Institute of Diabetes, Digestive and Kidney Disease. 2018. Hemorrhoids. Tersedia online di: https://www.niddk.nih.gov/health-information/digestivediseases/hemorrhoids/symptoms-causes [diakses pada 15 november 2018].

Thomas Barret. 2015. Hemorrhoids no more. USA: Living Plus Healthy Publishing.

Wax, Emily. 2016. High Fiber Foods. Tersedia online di https://medlineplus.gov/ency/patientinstructions/000193.htm [diakses pada 15 november 